\title{
ESCALATION OF COMMITMENT AND CEO DEPARTURES: THEORY AND EVIDENCE
}

\author{
Dmitriy V. CHULKOV (D) ${ }^{*}$, John M. BARRON ${ }^{2}$ \\ ${ }^{1}$ School of Business, Indiana University Kokomo, Kokomo, Indiana, USA \\ ${ }^{2}$ Krannert Graduate School of Management, Purdue University, West Lafayette, Indiana, USA
}

Received 25 October 2019; accepted 28 June 2021

\begin{abstract}
The escalation of commitment process involves a decision-maker continuing commitment to an investment after receiving negative information. This study develops a principal-agent model to explore how escalation decisions are linked with departures of CEOs from the position. With asymmetric information, a $\mathrm{CEO}$ has an incentive to conceal prior decision errors by escalating commitment to failing investments and leaving the firm before the outcome of investment decisions is disclosed publicly. Results of empirical analysis based on a sample of over 3,000 US firms are consistent with the theory and demonstrate that firms' reporting of low financial performance relative to their industry as well as initiation of new discontinued operations are preceded, and not followed, by unplanned CEO departures.
\end{abstract}

Keywords: escalation of commitment, discontinued operations, asymmetric information, principal-agent model, CEO turnover, labor economics.

JEL Classification: D82, G30, J63, M12, M50.

\section{Introduction}

Escalation of commitment exists when a decision-maker continues investments after receiving negative information. While studies in management and applied psychology identify a number of determinants contributing to the escalation of commitment (Staw \& Ross, 1987; Staw, 1997; Sleesman et al., 2012), this phenomenon has received relatively little analysis in economics. This study strives to fill the gap in the literature.

Prior research suggests a relationship between escalation of commitment and changes in the firm's management. This relationship comes from the personal responsibility effect according to which the person responsible for the original project selection decision is more likely to re-invest in the same project (Staw, 1976; Bazerman et al., 1984; Brody \& Frank, 2002). A change in management can therefore be used to stop runaway investments and

\footnotetext{
${ }^{\star}$ Corresponding author. E-mail: dchulkov@iu.edu
} 
de-escalate excessive commitment when new decision makers have no personal responsibility for the original decisions (Ross \& Staw, 1993; Staw et al., 1997; Keil \& Robey, 1999; Kalmanovich-Cohen et al., 2018; Chulkov \& Barron, 2019).

Research on the turnover of chief executive officers (CEOs) typically discusses the link between weak financial measures of firm performance and the subsequent departure of the CEO from the firm (Murphy \& Zimmerman, 1993; Jenter \& Kanaan, 2015; Gao et al., 2017). A general view in this literature is that departures of CEOs from the firm result from underperformance by the firm in the period leading to the departure. One theoretical basis for such a link is a disconnect between the requirements of the position and the ability of the CEO that may become apparent over time (Hermalin \& Weisbach, 2012; Anderson et al., 2018). As the ability of the CEOs is put in question by poor performance, their departure from the firm becomes more likely.

Escalation of commitment provides an alternative rationale for CEO departures from the firm. In this study, a principal-agent model of escalation behavior with asymmetric information is constructed such that a top executive acting as an agent is responsible for selecting a firm's investment portfolio and discovers the outcome of the firm's investments before it is publicly revealed. If the executive leaves the firm before the investment's outcome is made public, this helps mitigate damage to the executive's reputation.

This study provides several contributions to the economic literature on escalation and de-escalation of commitment, as well as the literature on CEO turnover. First, it links the incentive for escalation of commitment with the departure of the CEO from the firm in an economic model of asymmetric information. The theoretical model also implies that departures of CEOs from the firm are associated with subsequent de-escalation of commitment to failing investments. Second, escalation theory helps distinguish between different types of CEO departures from the firm. Not all such departures are similar in their motivation and impact on the firm. The incentive to escalate a failing project under asymmetric information contributes to an unplanned departure of a top executive in an attempt to protect reputation. In contrast, CEO departures that occur in a planned succession process are not likely to be associated with escalation of commitment. Third, the escalation theory provides new insights on the timing of the CEO departures' impact on the firm. Prior studies (e.g. Murphy \& Zimmerman, 1993; Jenter \& Kanaan, 2015) focused on explaining CEO departures from the firm based on underperformance by the firm prior to the CEO departure. In the presence of escalation of commitment, negative changes at the firm are observed not before the CEO departures, but after these, as the new leadership attempts to address escalated investments that may have been concealed by the departing executives. Furthermore, some failing investments escalated by an executive may be discovered by others while the executive is still employed at the original firm. When escalation of commitment is discovered, this may lead to a firing of the executive and resulting de-escalation actions. The observed impact of de-escalation of commitment is therefore expected not before, but after, unplanned CEO departures in a resignation or firing.

The paper examines the implications of the escalation theory for CEO departures empirically using a data set of over 3,000 U.S. firms covering the period from 1992 to 2018. The impact of escalation of commitment is revealed in de-escalation actions that follow CEO 
departures (Staw et al., 1997; Chulkov \& Barron, 2019). The empirical results demonstrate that significant economic changes at the firm are observed on financial statements published after the departure of a CEO. These changes include lower return on assets relative to firms in the same industry and initiation of new discontinued operations that are consistent with deescalation activities at the firm. Furthermore, the results indicate no significant link between CEO departures and economic changes at the firm for cases of departure due to planned succession or illness. Significant impact is observed only for unplanned CEO departures, consistent with the predictions of the theoretical model. Empirical analyses of large data samples focusing on escalation of commitment are rare, as most evidence on escalation comes from cases and experimental studies that examine dozens and not thousands of firms. Providing empirical evidence consistent with escalation and de-escalation of commitment contributes to the understanding of its impact.

The discussion proceeds as follows. Section 1 outlines the existing studies on escalation of commitment in the economic, managerial, and organizational literature. Section 2 develops a principal-agent model that links escalation of commitment with managerial turnover. Section 3 presents the hypotheses that follow from the theoretical analysis and outlines the empirical results. Section 4 discusses the implications of this study and is followed by the conclusion.

\section{Literature review}

Starting with the influential work of Staw (1976) that demonstrated the propensity of executives to commit resources to a failing course of action, researchers identified a number of factors linked to escalation of commitment. There are two related but separate strands of literature. Economic studies of escalation strive to identify rational explanations for continuing an investment after negative information has been received about it (Kanodia et al., 1989; Berg et al., 2009). In contrast, management and applied psychology literature typically views escalation as a deviation from good decision-making practice - an irrational process that is not in the interest of the firm (Staw \& Ross, 1987; Sleesman et al., 2012).

While economic research focusing on escalation of commitment is comparatively scarce, a major approach to explaining this phenomenon in economics is based on the principalagent model. Briefly, a decision that is not optimal for the firm may still be optimal for the manager when there is asymmetric information (Montecinos-Pearce et al., 2020). Suppose that a manager selects investments for the principal of the firm and then the manager discovers a project's failure before the principal may observe it. Then, the termination of the project by the manager serves as a signal that the manager's initial selection was not correct and thus damages the manager's reputation. Such reputation concerns were first discussed by Kanodia et al. (1989). Berg et al. (2009) conduct an experiment that demonstrates how asymmetric information between the principal and the agent may lead to escalation of commitment.

Research on escalation of commitment is much more common in management and applied psychology. The majority of these studies focus on the irrational aspect of escalation. In three prominent summaries of this literature, Staw and Ross (1987), Staw (1997), as well as Sleesman et al. (2012) create a classification of the major types of escalation determinants 
including psychological, social, and organizational or structural. The major psychological theory relevant for explaining escalation is self-justification. According to the self-justification theory (Staw, 1976; Brockner, 1992), decision makers rationalize their prior actions. As the result, they do not recognize prior mistakes and continue commitment to a course of action even after receiving negative information. A related idea is the personal responsibility effect which was shown to contribute to escalation of commitment as long as the original decision was later re-evaluated by the same decision maker (Staw, 1976; Brody \& Frank, 2002). More recently, Schulz-Hardt et al. (2009) demonstrate that the responsibility effect may be driven by the preferences of decision makers, while Schultze and Schulz-Hardt (2021) question the usefulness of responsibility reassignment as an effective intervention against escalating commitment based on experimental results. Psychological research on escalation behavior continues to explore new directions including the impact of such factors as emotions of fear and hope (Huang et al., 2019) and growth mindset (Lee et al., 2021).

Social determinants of escalation focus on an individual's interaction with others. Experiments indicate that decision makers invest more in a project and are more committed to it when others are also committed (Bazerman et al., 1984). They use modeling as they follow the behavior of others (Brockner, 1992). Organizational and structural factors contributing to escalation behavior include organizational inertia (Ross \& Staw, 1993). Due to organizational structure and breakdowns in communications, even when the organization recognizes the need for a different course of action, there is a lag before such a change may occur.

As the various escalation determinants were discovered by this expanding literature, other research focused on de-escalation and explored how firms reverse their course of action (Ohlert \& Weißenberger, 2020). De-escalation studies present factors that help reverse escalation of commitment including changes in leadership (Staw et al., 1997), separating the managers responsible for the investment and continuation decisions (Keil \& Robey, 1999), and evaluating managers based on their decision process and not on the ultimate results (Simonson \& Staw, 1992).

Much of the evidence on escalation and de-escalation of commitment comes from case studies and surveys. Staw et al. (1997) and Chulkov and Barron (2019) present two empirical studies that demonstrate how changes in the firm's management work as a de-escalation strategy. The following sections extend the economic literature on escalation with a principalagent model that specifically examines the role of executives' departures from the firm in creating the incentive to escalate commitment to an investment as well as the corresponding empirical evidence.

\section{A Model of Escalation and Executive's Departures from the Firm}

The theoretical model developed below focuses on the dilemma of top executives charged with matching their firm's portfolio of projects to the state of the world. The emphasis of the subsequent discussion and empirical test is on CEOs; however the model may apply to any top executive in this role.

In order to explore the economic incentives linking escalation of commitment with departure from the firm, the model adopts the simple setting of Kanodia et al. (1989), assuming 
that there are two types of executives - "smart" and "dumb". Smart executives are assumed to obtain a more informative signal for the project-selection decision that they face and therefore make better investment decisions. Neither the firm nor the executive know the executive's type at the outset. Both firms and executives are risk-neutral. Bayesian updating based on the observed events is used to determine an executive's probability of being smart, which may be viewed as the executive's reputation. Table 1 summarizes the timeline of events that is developed more fully below.

Table 1. Timeline of the model

\begin{tabular}{|l|l|}
\hline $\begin{array}{c}\text { Period of } \\
\text { the Model }\end{array}$ & \multicolumn{1}{c|}{ Summary of Events } \\
\hline Period 1 & $\begin{array}{l}\text { At the start of the period, the executive receives an imperfect signal concerning the } \\
\text { state of world; the signal quality depends on executive's type. The executive makes } \\
\text { investment decision based on the signal received. } \\
\text { The executive's compensation is based on the perceived ability of the executive. }\end{array}$ \\
\hline Period 2 & $\begin{array}{l}\text { At the start of the period, the executive obtains private information regarding the } \\
\text { true state of world; the executive makes the decision to continue or terminate the } \\
\text { investment. } \\
\text { The executive's compensation is based on the perceived ability of the executive. } \\
\text { At the end of the period, the executive makes the departure decision by comparing } \\
\text { the anticipated wage at the original firm with wage offers from other firms. }\end{array}$ \\
\hline Period 3 & $\begin{array}{l}\text { At the start of the period, the outcome of the investment is publicly revealed, } \\
\text { including whether the project matched the state of the world. } \\
\text { For executives who departed, compensation is based on the updated ability of the } \\
\text { departing executive. } \\
\text { For executives who remain, compensation is adjusted based on project outcome, and } \\
\text { in particular if escalation has occurred. }\end{array}$ \\
\hline
\end{tabular}

\subsection{Project selection decision in Period 1}

Consider the choice between two projects $-A$ and $B-$ by a top executive at the start of period 1. Success or failure of the chosen project depends in part on the subsequent state of the world. The state of the world can take on one of two values, $a$ or $b$, and either state is equally likely to occur. If project $A$ is chosen and state of the world $a$ is subsequently realized, then the project matches the state of the world. In order to focus on the executive's problem of matching projects to the state of the world, it is assumed that the two states are equally likely, and that projects $A$ and $B$ have identical positive returns $x_{H}>0$ when successfully matched to the state of the world and identical negative returns $x_{L}=-x_{H}$ when not successfully matched.

For a "dumb" executive, it is assumed that the project selection can be viewed as random, such that the project chosen is equally likely to match or not match the state of the world. In contrast, a "smart" executive is more likely to select the project correctly. That is, $1>\operatorname{Pr}(M \mid S)>\operatorname{Pr}(M \mid D)=1 / 2$, where $\operatorname{Pr}(M \mid S)$ and $\operatorname{Pr}(M \mid D)$ denote the probability that a project is correctly matched to the state of the world $(M)$ for a smart executive $(S)$ and for a dumb executive $(D)$, respectively. The initial ability of an executive is not known by either the firm or the executive. In particular, the initial likelihood the executive is smart as of the 
start of period 1 is denoted by $q_{1}$. Because smart executives are more likely to make project decisions that enhance the expected value of the firm, the updated likelihood the executive is smart at the start of period $t, q_{t}$, will influence wage offers made to the executive by firms.

Now consider departures of executives from the firm that can occur at the end of period 2 and their impact on the executives' reputation. To formalize an executive's departure decision in a simple fashion, suppose that the executive learns during the period of a non-pecuniary reward $z$ that will be experienced in the subsequent period if he or she remains with the current employer. The executive will depart if the expected value of remaining at the firm given the realized value of $z$ is below the expected value of leaving the firm. Let $z$ be drawn from a zero-mean distribution $F(z)$. Thus, there is some underlying rate of executive departures at the end of the period. This may encompass a variety of exogenous factors including departures due to personal circumstances or illness. This simple view of turnover is adopted to focus on the incentives for escalation behavior, and follows Lippman and McCall (1981) in assuming that the value of the employee-firm match is linked to the revelation of a nonpecuniary attribute to the employee's return from continued employment.

\subsection{Project continuation decision in Period 2}

An executive acting as an agent is likely to discover the appropriateness of a project before the principal of the firm. It is assumed that the executive learns whether the investment matched the state of the world at the start of period 2 which is before this information is publicly revealed to others. The information asymmetry makes the executive better informed than the principal of the firm or alternative employers at this time. If the executive learns that the project matches the state of the world, the expected return to continuing the project to completion is sufficiently high so that the executive would choose to continue the project. The probability of a successful match is denoted by:

$$
p=q_{1} \operatorname{Pr}(M \mid S)+\left(1-q_{1}\right) \operatorname{Pr}(M \mid D) .
$$

From the point of view of the firm, a project that does not match the state of the world should be terminated in period 2, with the associated assets reallocated to more profitable uses. However, the executive has the option of continuing a project into period 3 even if the project does not match the state of the world. Such continuation is by definition an instance of escalation of commitment and is not in the best interest of the firm. It is assumed that there is a direct non-recoverable cost to the firm of postponing project termination and that the firm is able to impose it on the executive if the executive remains with the firm.

\subsection{Bayesian updating of reputation in Period 2}

Consider how the firm may use Bayesian updating to determine the probability the executive is of the smart type based on the observable information at various points. This probability reflects the executive's reputation. At the start of period 2, the firm updates its perception of the executive's ability $q_{2}$ based on whether the selected project was continued. Assume that the fraction $a$ of projects that are discovered by executives in period 2 to be mismatched to 
the state of the world are nevertheless continued, making the parameter $a$ an indicator of the extent to which escalation of commitment occurs. If the executive continues $(C)$ the project, then period 2's updated probability that the executive is smart is given by expression (1).

$$
q_{2}^{C}=\frac{q_{1}(\operatorname{Pr}(M \mid S)+(1-\operatorname{Pr}(M \mid S)) a)}{q_{1}(\operatorname{Pr}(M \mid S)+(1-\operatorname{Pr}(M \mid S)) a)+\left(1-q_{1}\right)(\operatorname{Pr}(M \mid D)+(1-\operatorname{Pr}(M \mid D)) a)} .
$$

On the other hand, when an executive terminates $(T)$ the project that is discovered to not match the state of the world, the firm's perception the executive is smart is given by (2).

$$
q_{2}^{T}=\frac{q_{1}(1-\operatorname{Pr}(M \mid S))(1-a)}{q_{1}(1-\operatorname{Pr}(M \mid S))(1-a)+\left(1-q_{1}\right)(1-\operatorname{Pr}(M \mid D))(1-a)} .
$$

If escalation is not chosen in all cases $(a<1)$ then it follows that $q_{2}^{C}>q_{1}$ and $q_{2}^{T}<q_{1}$. Therefore, executives who escalate commitment to a project that has not matched the state of the world can temporarily enhance both their reputation and their wage. This gain comes from being able to pool with executives who have matched the project to the state of the world correctly.

\subsection{Link between escalation and departure from the firm}

In the timeline of the model, the firm ultimately discovers whether the project was matched to the state of the world in period 3. At that point, the firm can impose costs on the executive in order to recover the project continuation expenses as well as to discourage future escalation behavior by other executives. Therefore, if an executive continued a project that did not match the state of the world, in period 3 this escalation of commitment and the resulting misallocation of resources becomes public if the executive remains at the firm. The executive's wage will also adjust downward given that the wage incorporates the realization that the prior continuation of the investment project did not reflect a matching of the project with the state of the world. That is, the updated reputation of the escalating executive who remains at the firm $(R)$ is $q_{3}^{R}=q_{2}^{T}<q_{2}^{C}$. Note that these adverse actions by the firm are publicly observable, and so the reputation and the potential wages of an executive who escalated commitment to a mismatched project and stayed at the firm decline not only at the original firm, but also at other firms that may offer employment to the executive.

The executive has the option to depart from the firm at the end of period 2. Note that if the executive departs before escalation is discovered, the executive can avoid costs or penalties resulting from escalation that otherwise would have been imposed by the original firm. It is assumed that external firms may observe with certainty that an executive's matching of the projects was not correct only if there is a direct action - either a termination of the investment project by the executive in period 2, or a penalty such as a reduction in wage for an executive who is still with the original firm in period 3. Therefore, an executive who leaves the original firm can take advantage of higher wages associated with an enhanced reputation at alternative employers who are not privy to full information regarding the executive's prior mismatching of investments to the state of the world. 
This follows from the existence of random turnover in every period due to the realization of non-pecuniary return $z$, such that an executive who leaves the firm due to escalation behavior is pooled with other executives leaving the firm for exogenous reasons.

A key conclusion of this theoretical analysis is that for some executives who learn that their investment choices do not match the state of the world, engaging in escalation of commitment to a failing project can provide a net benefit when it is combined with the option of departure from the firm. The benefit of leaving the firm given the escalation decision has two components. First, departure from the firm reduces the damage to the executive's reputation in period 3 as turnover pools the executive who has mismatched the project to the state of the world with executives who have not. Second, departure allows the executive to escape any penalties for escalation imposed by the firm. Such penalties can reflect reduced bonuses or incentive pay based on reports at the start of period 3 regarding the firm's performance in the prior period. Note also that since executive turnover for exogenous reasons is pooled with departures by executives choosing to avoid the costs of escalation at the original firm, there is an overall negative effect of turnover on reputation for all executives leaving their firms. The highest reputation in the sense of the probability of the executive being the smart type will be achieved by the executives who match their projects correctly to the state of the world and then stay with their original firm.

\section{Empirical evidence on CEO departures and de-escalation of commitment}

The theoretical analysis above establishes the incentive for executives who learn of an impending failure of the firm's investments they were responsible for to escalate commitment and depart from the firm before the poor performance is publicly revealed. This implies that departures of top executives are expected to occur before the negative economic changes associated with de-escalation of commitment are observed publicly. The analysis below tests this implication of the escalation theory empirically.

\subsection{Background and hypotheses}

The connection between executive turnover and escalation of commitment has been suggested by a number of empirical and experimental studies that identified the personal responsibility effect (Staw, 1976; Bazerman et al., 1984) in that an executive responsible for the project selection decision is more likely to continue the investment. A departure of such an executive from the decision-making position removes the incentive to escalate commitment (Staw et al., 1997; Keil \& Robey, 1999; Kalmanovich-Cohen et al., 2018). The new leadership is free from having personal responsibility for the choices made by departed executives and can adjust the firm's operations in the best interest of the firm. Therefore, CEO departures from the firm can have a negative economic impact on the firm's financial performance as investment decisions are reversed and resources are reallocated to alternative uses.

Empirical studies of CEO turnover by Barron et al. (2011) as well as Chulkov and Barron (2019) demonstrated that CEO departures, especially forced departures and contender successions, are associated with negative changes at the firm including increased likelihood 
of discontinued operation reports at the time when top executives are leaving the firm and underperformance on financial measures such as net income and market value. This study extends the prior research by examining the predictions of the asymmetric information model of escalation behavior.

This theoretical model is novel. Its implications on the timing of events around CEO departures are different from the view of unplanned turnover in prior studies. Such turnover is typically seen as the outcome of reported poor performance by the firm over one-to-two years prior to the CEO departure (Jenter \& Kanaan, 2015; Gao et al., 2017). That is, given that annual financial reports for fiscal year $t$ are made public at the start of fiscal year $t+1$, one would expect poor performance in year $t$, confirmed publicly at the start of year $t+1$, to be linked to CEO turnover in year $t+1$. In other words, under the standard approach to turnover, one would expect poor firm performance in year $t$ to be linked to CEO departures during the year after the poor performance, which is year $t+1$. Note that during the sample period, the U.S. SEC annual report filing deadlines required annual performance reports be made public within 60 to 90 days after the end of the fiscal year, which corresponds to the start of fiscal year $t+1$.

On the other hand, the escalation-of-commitment model postulates that CEOs obtain private asymmetric information on firm performance. In this case, CEOs in year $t$ anticipate performance reports for year $t$ that will be made public at the start of year $t+1$. A CEO who anticipates a poor performance report at the start of year $t+1$ has a greater incentive to depart from the firm during year $t$. That is, under the escalation-of-commitment view, one would expect poor firm performance measures in year $t$ to be linked to CEO departures in the fiscal year before the performance measure is made public at the start of year $t+1$, and this link will be observed in year $t$. Hypotheses 1 and 2 provide the expectations for the overall impact of CEO departures on the firm in the presence of asymmetric information.

Hypothesis 1. CEO departures from the firm are observed in the fiscal year prior to the public reporting by the firm of adverse financial performance.

Hypothesis 2. CEO departures from the firm precede new discontinued operations reported by the firm.

While Hypotheses 1 and 2 provide a general view, the principal-agent model of escalation behavior also suggests a more nuanced link between CEO departures and changes in the firm's performance and operations that helps distinguish between different types of CEO departures. Not all CEO departures from the firm are expected to have the connection with asymmetric information and escalation behavior. In terms of the theoretical model, there is underlying turnover driven by non-pecuniary factors. This includes departures not only due to such factors as illness or death but also departures that reflect planned successions. These are typically not in direct reaction to the realization of poor performance anticipated by the CEO. Furthermore, planned successions typically result in follower CEOs who are less likely to introduce major changes (Shen \& Cannella, 2002; Barron et al., 2011).

There are two major types of unplanned CEO departures in which asymmetric information and the resulting anticipatory departure behavior can arise. First, a CEO can escalate commitment to failing investments, and then leave the firm voluntarily before the outcome 
is publicly observed. This departure helps escape reputation damage. Second, the failure of investments selected by the executive may be discovered by others at the firm before the executive has the chance to depart. In this case, a forced departure of the CEO may occur in a firing. These unplanned departures, whether voluntary or forced, are expected to be associated with subsequent adverse performance reports by the firm as well as new discontinued operations. Hypotheses 3 and 4 describe the expected impact of unplanned $\mathrm{CEO}$ departures in the presence of asymmetric information and the resulting escalation-ofcommitment behavior.

Hypothesis 3. Unplanned CEO departures from the firm are observed in the fiscal year prior to the public reporting by the firm of adverse financial performance.

Hypothesis 4. Unplanned CEO departures from the firm precede reports of new discontinued operations.

\subsection{Data and variable selection}

In order to study the proposed connection between escalation behavior and CEO departures empirically, an extensive data set of publicly-traded U.S. firms is used. It is constructed starting with the ExecuComp compensation data for the period from 1992 through 2018. These data are merged with the CompuStat data set of financial variables. The merged data set contains 3,819 firms and a total of 56,214 firm/year observations. Eleven speculative investment firms that appear in the data set for at least 10 years but never report a positive return on assets are excluded. The data set also excludes observations in which the CEO at the start of the fiscal year is not well-defined; these are cases when there were co-CEOs and cases when the CEO was shared across firms. The data set also excludes firm/year combinations that involve a restructuring of the firm spinoff, buyout, merger, or bankruptcy - and firm/year combinations that are missing key financial variables such as the size of assets or the rate of return on assets. At this point, the data sample includes 3,757 distinct firms with 50,112 firm/year observations.

In order to identify CEO turnover based on changes in the CEO at a firm from year to year, unique firm identification numbers are introduced to distinguish contiguous time periods. This means that when there is a break in data availability for a particular firm, two separate firm identification numbers are created which results in 4,022 distinct contiguous-period observations. To focus on turnover identification, only firm observations that extend over at least six contiguous years are kept in the sample. This reduces the sample to 3,061 firms and 46,809 distinct firm/year observations.

To identify the year of a CEO departure, the CEO at the start of each year is identified for each firm. This also helps identify the last year an individual served as CEO. This information is used to calculate the tenure of each CEO. For CEOs who occupied the position when the firm enters the sample, information in the ExecuComp data set regarding the date when the individual first became the CEO is used to compute the CEO's tenure.

Cases involving the last year the firm is in the sample are excluded as the departure year for the CEO cannot be clearly identified. This results in a sample of 3,061 firms reflecting 43,748 firm/year combinations over the period from 1992 to 2017. For this 
sample, the procedure proposed by Parrino (1997) is followed to examine news articles related to CEO turnover in order to verify the timing of such turnover and to confirm the reasons for each CEO departure case. As the empirical analysis includes lagged financial variables, the first year a firm is present in the sample is also dropped, resulting in the final sample size of 3,061 firms and 40,813 observations.

For this sample, six categories of CEO departures are identified. These categories are classified into three broad groups - departures due to exogenous reasons, planned successions, and unplanned departures. The first group includes executives who left their position due to illness or death. This category may be viewed as truly exogenous and therefore can provide a baseline for examining the impact of other departure types. The second group of departures includes two categories - CEOs who have been identified as having retired at the age of 60 or higher and CEOs who have taken on a new position within the firm. These CEOs who change duties typically move to a senior position on the board of directors and maintain their connection with the firm. This second group represents planned succession events. The third group of departures focuses on unplanned turnover that happens outside of a planned succession process. This category includes three types of departures - CEOs who resigned from the firm, CEOs who retired before the age of 60 , and those who were fired. Table 2 presents a breakdown of the observed CEO departures in the research sample. Note that interim CEOs are not included in the sample.

Table 2. CEO departure types in the data sample

\begin{tabular}{|l|c|c|}
\hline & $\begin{array}{c}\text { Number of CEO } \\
\text { departures* }\end{array}$ & $\begin{array}{c}\text { Percent of CEO } \\
\text { Departures by Reason }\end{array}$ \\
\hline All CEO Departures & 3,596 & $100.00 \%$ \\
\hline 1. CEO Illness or Death & 127 & $3.5 \%$ \\
\hline 2. Planned Succession Departures Total & 2,015 & $56.0 \%$ \\
\hline CEO Changed Duty & 435 & $12.1 \%$ \\
\hline CEO Retired at Age 60 or over & 1,580 & $43.9 \%$ \\
\hline 3. Unplanned Departures Total & 1,454 & $40.4 \%$ \\
\hline CEO Resigned & 370 & $10.3 \%$ \\
\hline CEO Retired Early & 886 & $24.6 \%$ \\
\hline CEO Fired & 198 & $5.5 \%$ \\
\hline
\end{tabular}

Note: ${ }^{\star}$ Excludes interim CEOs who had tenure of 2 years or less.

Two independent variables are introduced to identify the timing of financial reporting relative to CEO departures. The first is a dummy variable equal to one if the year of the observation and the associated financial data reflects the last year the CEO was employed. As key financial performance data such as the return on assets and the impact of discontinued operations for the year are not reported until the start of the next fiscal year, this CEO departure year variable indicates that annual performance data have not yet been publicly announced at the time of the CEO departure. That is, it indicates a CEO departure in the 
year before the reported financial performance data. The second dummy variable equals one if the year of the observation and the associated financial data is prior to the observed CEO departure year. This variable indicates that the CEO departure happens in the year after the reported financial performance data.

Several empirical specifications are utilized with these two separate departure-timing variables. The first dependent variable focuses on firm performance. The analysis follows Jenter and Kanaan (2015) who advocated using a relative measure of the firm's performance compared to the other firms in the same industry in evaluating CEO turnover. To measure relative performance, the difference between a firm's reported annual rate of return on assets and the average rate of return for other firms in the same industry by two-digit NAICS code is calculated. This measure identifies performance as reported by the firm at the end of each fiscal year relative to its industry in the same fiscal year.

The second dependent variable captures new reporting of discontinued operations by the firm. This measure is used consistently with prior studies by Statman and Sepe (1989) and Barron et al. (2011) to capture realignment of a firm's investments. As the reporting of discontinued operations linked to one investment often happens over several annual reports, the first report in each sequence is identified. Thus, the second dependent variable equals one if the firm initiated a new sequence of discontinued operations in the fiscal year. This dependent variable provides a measure of newly reported de-escalation activities.

Over the majority of the sample period starting from 2002, discontinued operations in U.S. accounting standards were defined following the FASB Statement 144. However before 2002, the rules of the Accounting Principles Board (APB) Opinion 30 were followed. Under APB 30, only dispositions of business segments were classified as discontinued operations, with business segments generally defined as a customer class or major business line. One result of this change is that fewer asset disposals qualify as discontinued operations prior to 2002 in the research sample. Other studies (Barua et al., 2010; Kaplan et al., 2020) report similar patterns. Note that this study focuses on first occurrences of discontinued operations in a sequence. Most of the increase in the frequency of discontinued operations arising from the accounting change in 2002 reflects an increase in the number of adjacent years with discounted operation reports. Compared to this increase, the rise in the frequency of new sequences of discontinued operations is of second order. Furthermore, fiscal year control variables are included to capture the impact of annual differences in the overall level of discontinued operations. An unreported robustness test also checks whether the accounting standard change might affect the empirical results by introducing additional variables that interact the CEO departure timing variables with a variable that indicates the years prior to 2002. All empirical results are robust to such an adjustment.

Table 3 presents the summary statistics for the research sample. The empirical analysis includes control variables that capture firm-specific characteristics including log values of the firm's total assets, the ratio of market- to book-value of assets and the ratio of R\&D expenditures to book-value of assets, as well as a set of fiscal year dummy variables. 
Table 3. Summary statistics

\begin{tabular}{|l|c|c|c|c|c|c|}
\hline \multicolumn{1}{|c|}{ Variable } & $\begin{array}{c}\text { Number } \\
\text { of Obs. }\end{array}$ & Mean & Std. Dev. & Median & Min & Max \\
\hline $\begin{array}{l}\text { Difference from industry return } \\
\text { on assets (Dependent) }\end{array}$ & 40,813 & 0.011 & 0.155 & 0.011 & -5.862 & 10.979 \\
\hline $\begin{array}{l}\text { New discontinued operations } \\
\text { reported (Dependent) }\end{array}$ & 40,813 & 0.058 & 0.233 & 0 & 0 & 1 \\
\hline $\begin{array}{l}\text { Prior log of book value of total } \\
\text { assets }\end{array}$ & 40,813 & 7.809 & 1.781 & 7.685 & 1.365 & 15.075 \\
\hline $\begin{array}{l}\text { Prior ratio: R\&D to book value } \\
\text { of assets }\end{array}$ & 40,813 & 0.027 & 0.077 & 0 & 0 & 9.252 \\
\hline $\begin{array}{l}\text { Prior ratio: Market to book } \\
\text { value of assets }\end{array}$ & 40,813 & 1.417 & 2.091 & 0.931 & 0 & 105.032 \\
\hline CEO departure year $\star$ & 40,813 & 0.088 & 0.283 & 0 & 0 & 1 \\
\hline $\begin{array}{l}\text { CEO departure year: illness or } \\
\text { death }\end{array}$ & 40,813 & 0.003 & 0.056 & 0 & 0 & 1 \\
\hline $\begin{array}{l}\text { CEO departure year: planned } \\
\text { succession }\end{array}$ & 40,813 & 0.049 & 0.217 & 0 & 0 & 1 \\
\hline $\begin{array}{l}\text { CEO departure year: } \\
\text { unplanned succession }\end{array}$ & 40,813 & 0.036 & 0.185 & 0 & 0 & 1 \\
\hline Fiscal Year & 40,813 & 2005.5 & 6.994 & 2006 & 1993 & 2017 \\
\hline
\end{tabular}

Note: ${ }^{*}$ Dummy variables that identify CEO departure in the fiscal year before a given financial report is posted and CEO departure in the year after the date of the financial report have similar statistics.

\subsection{Empirical results}

Several empirical models are used to examine the relationships between the dependent variables and the timing of CEO departures from the position. The analysis starts by establishing the simple correlations with an OLS regression in model (1). Then a set of control variables and fiscal year dummy variables are added in model (2). Model (3) introduces firm-level fixed effects. This helps abstract from the differences across firms that could be correlated with both the independent variables of CEO departure timing as well as the dependent variables (Chamberlain, 1980). Finally, for the fixed effects specifications, model (4) introduces the separation of CEO departures by type.

The results for the first dependent variable - relative rate of return on assets - are reported in Table 4. Results of model (1) and model (2) indicate that a firm is likely to report significantly lower performance compared to other firms in the same industry when the CEO departs in the fiscal year before the announcement of the annual earnings and the rate of return. This relationship is significant at the 1-percent level. Such underperformance also occurs when the departure of the CEO occurs in the year after the earnings report date, but not to the same degree. After introducing firm-level fixed effects in model (3) to control for differences across firms, the key result is that departures tend to anticipate, not react to, lower performance. This finding is supportive of Hypothesis 1. 
Table 4. Relative return on assets surrounding departures of CEOs

\begin{tabular}{|c|c|c|c|c|}
\hline \multirow[b]{2}{*}{ Independent variables } & Model (1) & Model (2) & Model (3) & Model (4) \\
\hline & OLS & OLS & $\begin{array}{l}\text { Fixed } \\
\text { effects }\end{array}$ & $\begin{array}{l}\text { Fixed } \\
\text { effects }\end{array}$ \\
\hline $\begin{array}{l}\text { CEO departure in the year before earnings } \\
\text { reporting date }\end{array}$ & $\begin{array}{l}-0.0250^{\star *} \\
(-9.22)\end{array}$ & $\begin{array}{l}-0.0245^{* *} \\
(-9.21)\end{array}$ & $\begin{array}{l}-0.0190^{\star *} \\
(-7.79)\end{array}$ & \\
\hline $\begin{array}{l}\text { CEO departure in the year after earnings } \\
\text { reporting date }\end{array}$ & $\begin{array}{c}-0.00562^{\star} \\
(-2.05)\end{array}$ & $\begin{array}{l}-0.0070^{* *} \\
(-2.60)\end{array}$ & $\begin{array}{c}-0.0010 \\
(-0.40)\end{array}$ & \\
\hline Prior year log of book value of total assets & & $\begin{array}{c}0.0030^{* *} \\
(6.82)\end{array}$ & $\begin{array}{c}-0.0221^{\star *} \\
(-14.99)\end{array}$ & $\begin{array}{l}-0.0218^{* *} \\
(-14.81)\end{array}$ \\
\hline $\begin{array}{l}\text { Prior year ratio of R\&D to book value of } \\
\text { assets }\end{array}$ & & $\begin{array}{l}-0.301^{* *} \\
(-28.23)\end{array}$ & $\begin{array}{l}-0.0531^{* *} \\
(-3.74)\end{array}$ & $\begin{array}{l}-0.0522^{* *} \\
(-3.68)\end{array}$ \\
\hline $\begin{array}{l}\text { Prior year ratio of market to book value of } \\
\text { assets }\end{array}$ & & $\begin{array}{c}0.0129^{* *} \\
(32.64)\end{array}$ & $\begin{array}{c}0.0080^{* *} \\
(18.27)\end{array}$ & $\begin{array}{c}0.0080^{* *} \\
(18.24)\end{array}$ \\
\hline $\begin{array}{l}\text { CEO departure in the year before earnings } \\
\text { reporting date: illness or death }\end{array}$ & & & & $\begin{array}{c}-0.0033 \\
(-0.27)\end{array}$ \\
\hline $\begin{array}{l}\text { CEO departure in the year before earnings } \\
\text { reporting date: planned succession }\end{array}$ & & & & $\begin{array}{c}-0.0034 \\
(-1.08)\end{array}$ \\
\hline $\begin{array}{l}\text { CEO departure in the year before earnings } \\
\text { reporting date: unplanned succession }\end{array}$ & & & & $\begin{array}{c}-0.0428^{* *} \\
(-11.32)\end{array}$ \\
\hline $\begin{array}{l}\text { CEO departure in the year after earnings } \\
\text { reporting date: illness }\end{array}$ & & & & $\begin{array}{c}0.0141 \\
(1.10)\end{array}$ \\
\hline $\begin{array}{l}\text { CEO departure in the year after earnings } \\
\text { reporting date: planned succession }\end{array}$ & & & & $\begin{array}{c}0.0022 \\
(0.68)\end{array}$ \\
\hline $\begin{array}{l}\text { CEO departure in the year after earnings } \\
\text { reporting date: unplanned succession }\end{array}$ & & & & $\begin{array}{c}-0.0075 \\
(-1.94)\end{array}$ \\
\hline Fiscal year control variables & & Included & Included & Included \\
\hline Observations & 40,821 & 40,821 & 40,821 & 40,821 \\
\hline F-statistic & 43.21 & 61.78 & 38.95 & 36.42 \\
\hline
\end{tabular}

Note: $t$-statistics in parentheses: ${ }^{\star} \mathrm{p}<.05,{ }^{* *} \mathrm{p}<.01$.

Estimation of model (4) reveals that this relationship between a CEO departure and subsequent lower performance is driven by a single category of CEO departures, and that category is unplanned departures of the CEO in the year before the earnings reporting date. The coefficient for this category is significant at the 1-percent level and no significant relationships are observed for the other types of CEO departures. This evidence supports Hypothesis 3 .

The second dependent variable equals one if the firm initiated a new sequence of discontinued operations and so logit models are utilized to examine its relationship with CEO departures. The results for these estimations are presented in Table 5. In addition to a simple logit model (1), the impact of control variables and fiscal year dummy variables is examined in model (2). Model (3) introduces firm-level fixed effects and model (4) examines CEO departures by type. 
Table 5. New discontinued operation reporting surrounding departures of CEOs

\begin{tabular}{|c|c|c|c|c|}
\hline \multirow[b]{2}{*}{ Independent variables } & Model (1) & Model (2) & Model (3) & Model (4) \\
\hline & Logit & Logit & $\begin{array}{c}\text { Fixed } \\
\text { Effects } \\
\text { Logit }\end{array}$ & $\begin{array}{c}\text { Fixed } \\
\text { Effects } \\
\text { Logit }\end{array}$ \\
\hline $\begin{array}{l}\text { CEO departure in the year before earnings } \\
\text { reporting date }\end{array}$ & $\begin{array}{l}0.0259^{* *} \\
(7.35)\end{array}$ & $\begin{array}{l}0.0244^{* *} \\
(6.94)\end{array}$ & $\begin{array}{c}0.0136^{*} \\
(2.53)\end{array}$ & \\
\hline $\begin{array}{l}\text { CEO departure in the year after earnings } \\
\text { reporting date }\end{array}$ & $\begin{array}{c}0.00968^{*} \\
(2.44)\end{array}$ & $\begin{array}{c}0.0079^{*} \\
(1.99)\end{array}$ & $\begin{array}{l}0.0008 \\
(0.26)\end{array}$ & \\
\hline Prior year log of book value of total assets & & $\begin{array}{c}0.0029^{* *} \\
(4.14)\end{array}$ & $\begin{array}{c}0.0186^{* *} \\
(4.52)\end{array}$ & $\begin{array}{c}0.0190^{* *} \\
(4.56)\end{array}$ \\
\hline $\begin{array}{l}\text { Prior year ratio of R\&D to book value of } \\
\text { assets }\end{array}$ & & $\begin{array}{l}-0.0162 \\
(-0.64)\end{array}$ & $\begin{array}{l}0.132^{*} \\
(2.41)\end{array}$ & $\begin{array}{l}0.136^{*} \\
(2.41)\end{array}$ \\
\hline $\begin{array}{l}\text { Prior year ratio of market to book value of } \\
\text { assets }\end{array}$ & & $\begin{array}{c}-0.0127^{\star *} \\
(-9.79)\end{array}$ & $\begin{array}{c}-0.0096^{*} \\
(-2.40)\end{array}$ & $\begin{array}{c}-0.0099^{*} \\
(-2.40)\end{array}$ \\
\hline $\begin{array}{l}\text { CEO departure in the year before earnings } \\
\text { reporting date: illness or death }\end{array}$ & & & & $\begin{array}{c}0.0057 \\
(0.36)\end{array}$ \\
\hline $\begin{array}{l}\text { CEO departure in the year before earnings } \\
\text { reporting date: planned succession }\end{array}$ & & & & $\begin{array}{l}0.0078 \\
(1.62)\end{array}$ \\
\hline $\begin{array}{l}\text { CEO departure in the year before earnings } \\
\text { reporting date: unplanned succession }\end{array}$ & & & & $\begin{array}{c}0.0228^{* *} \\
(2.58)\end{array}$ \\
\hline $\begin{array}{l}\text { CEO departure in the year after earnings } \\
\text { reporting date: illness }\end{array}$ & & & & $\begin{array}{l}-0.0108 \\
(-0.56)\end{array}$ \\
\hline $\begin{array}{l}\text { CEO departure in the year after earnings } \\
\text { reporting date: planned succession }\end{array}$ & & & & $\begin{array}{c}-0.0033 \\
(-0.72)\end{array}$ \\
\hline $\begin{array}{l}\text { CEO departure in the year after earnings } \\
\text { reporting date: unplanned succession }\end{array}$ & & & & $\begin{array}{c}0.00732 \\
(1.32)\end{array}$ \\
\hline Fiscal year control variables & & Included & Included & Included \\
\hline Observations & 40,821 & 40,821 & 23,326 & 23,326 \\
\hline Log Likelihood & -8977 & -8708 & -5434 & -5430 \\
\hline
\end{tabular}

Note: $t$-statistics in parentheses: ${ }^{\star} \mathrm{p}<.05,{ }^{* *} \mathrm{p}<.01$.

Logit models (1) and (2) demonstrate that CEO departures are linked to an increase in the likelihood of reporting a new sequence of discontinued operations. Similar to the results for rate of return on assets reported in Table 4, these results are stronger in both coefficient size and significance for CEO departures preceding the financial reports. The relationship is significant at the 1-percent level. Adding fixed-effects in model (3) reveals that the coefficient for new discontinued operations when CEO departure occurs in the year before the financial reporting date is significant at the 5-percent level, but that is not the case for departures in the year after the reporting date. This evidence supports Hypothesis 2. Further, the results for fixed-effects logit model (4) confirm that the relationship between CEO departures and discontinued operations is significant only for the category of unplanned CEO departures in the year before the financial report in which the new sequence of discontinued operations appears. This evidence supports Hypothesis 4. 
Simple two-way t-tests were performed to compare the effect of the key independent variables of CEO turnover timing on both of the dependent variables from Tables 4 and 5 . These tests confirm that the relative rate of return is lower and the likelihood of a discontinued operation report is higher and significantly different from the mean when there is CEO departure in the year before the financial reporting date but that such differences are not statistically significant when the CEO departures are observed in the year after the financial reporting date.

\section{Discussion}

This paper examines the connection between CEO departures from the firm and escalation of commitment. The theoretical model demonstrates that an executive who has learned of an impending failure of an investment has the incentive to escalate commitment to it and attempt to leave the firm before its outcome is revealed publicly. The empirical results reported in Tables 4 and 5 confirm this predicted pattern as only CEO departures that are unplanned and that occur in the fiscal year before a given financial report is published are linked to adverse firm performance and new discontinued operations. These results, based on an exceptionally large data set, complement earlier studies on de-escalation at the time of management change (Kalmanovich-Cohen et al., 2018; Chulkov \& Barron, 2019). The focus of this analysis on the timing of financial reports is closer to the work of Staw et al. (1997) on escalation of commitment and write-offs around bank manager departures. In a much larger sample, significant changes in the relative rate of return and discontinued operations are observed following the CEO departure confirming the findings of Staw et al. (1997).

The approach of the current study is also similar to that of Jiang et al. (2017), who point out that executives in declining firms may engage in ship-jumping behavior and voluntarily move to new employers before the failure is observed to avoid the stigma. Building on a network embeddedness perspective in a study of Chinese firms, they identify such networkbased indicators as the executive's social capital and the declining firm's alliance network that influence the CEO departure decision by shaping its benefits and opportunity costs. The model presented in section 2 and the empirical results in section 3 support the idea that executive departures may be used to protect reputation. However, Jiang et al. rely on a sample that only includes firms with declining performance in order to focus on variables that influence the costs and benefits of such a departure. In contrast, the focus of this study is on the timing of the departure, and in particular whether certain departure types are associated with subsequent underperformance at the firm. In addition, the data set used by Jiang et al. reflects a much smaller sample of departures of Chinese executives who are typically not CEOs and are much earlier in their careers.

While the empirical analysis in this paper is consistent with the economic model of escalation of commitment, alternative explanations for the findings are possible. For instance, there can be changes driven by the firm's environment such as the fit-drift/shift-refit model (Finkelstein et al., 2009; Chen \& Hambrick, 2012). The environment shift can result in initially good investments becoming unfit and requiring changes at the firm. Barron et al. (2011) demonstrate that strategic changes at the firm are more likely after specific types of CEO 
departures including contender and outsider successions, as well as after departures that include non-CEO members of the top management team.

The current study is limited by the fact that it is based on a subset of publicly-traded U.S. firms. While the sample clearly identifies departures of CEOs and other top executives from a firm, it cannot identify all the destinations of executives moving to positions in private and international firms. To examine this issue, the destinations of departing executives that appear again at different firms within the sample were identified. Ultimately, a sub-sample was created that included 185 executives who, having departed one firm as the CEO, appear later as one of the top executives at other firms within the data set. Close to 90 -percent of these cases involve reemployment at only one other firm within the sample period. As expected in an escalation-of-commitment setting, individuals who left the firm in an unplanned succession were more likely to be identified as finding employment at another firm. Overall, 13.2-percent of CEO resignations were followed by re-employment in a top-management position. Meanwhile, only 3.8-percent of firings and 2.7-percent of retirements were followed by re-employment within the sample. CEOs leaving in an unplanned succession also tended to have a shorter period of time before becoming re-employed, and had compensation at the new employer that was higher than the compensation at the firm they departed from. Specifically, 68-percent of the resigning executives in the sub-sample found re-employment within two years and their compensation was 86-percent higher at their new firms. No evidence of higher compensation at the new firm was found for those executives who retired or were fired. The analysis based on these data is suggestive, but given the relatively small size of the re-employment sub-sample and potential selection bias in the firms re-employing the departing executives, a complete study of CEO re-employment remains an area for future research.

\section{Conclusions}

This study explores the link between the incentive to escalate commitment to an investment and turnover by CEOs. CEO departures are complex events that are unlikely to be explained by a single perspective. Escalation of commitment provides a novel theoretical basis for CEO departures from the firm. In the principal-agent model, information asymmetry creates an incentive for a $\mathrm{CEO}$ to continue failing investments and thus limit public revelation of prior mistakes. It also means that a CEO has the incentive to leave the firm before investment outcomes are publicly reported. The contribution of this paper lies in formalizing the economic principal-agent model of escalation behavior and in employing econometric analysis based on 3,061 US firms over a quarter of a century to test the resulting hypotheses. The finding that reporting of adverse financial performance relative to the industry as well as new discontinued operations are preceded, and not followed, by unplanned CEO departures supports the escalation of commitment theory. These changes are consistent with de-escalation activities at the firm subsequent to a CEO departure. No significant relationships are observed between CEO departures and economic changes at the firm for cases of departure due to planned succession or illness.

While the data set used in this study is extensive and provides generalizable results, a limitation is the level of granularity of the data that does not allow for examining the exact 
motivation for each CEO departure beyond the basic classification. There exists a trade-off between the granularity of the data and the size of the data sample. A smaller-scale empirical study that may track specific motivations for CEO departures in the context of escalation of commitment remains a direction for future research.

The implications of this study for future theoretical and empirical work follow from the connection it identifies between the research on CEO turnover and the studies on escalation of commitment. This link provides a rationale for CEO turnover that has not been explored in economic studies. Another implication for business decision makers and researchers is that unplanned CEO departures from the firm serve as an indicator of impending negative changes at the firm due to the potential for discovery of escalated investments. Taking the link between escalation of commitment and unplanned CEO turnover into account helps develop organizational policies designed to address the escalation-of-commitment phenomenon.

\section{Disclosure statement}

The authors declare no competing financial, professional, or personal interests from other parties.

\section{References}

Anderson, R., Bustamante, M., Guibaud, S., \& Zervos, M. (2018). Agency, firm growth, and managerial turnover. The Journal of Finance, 73(1), 419-464. https://doi.org/10.1111/jofi.12583

Barron, J., Chulkov, D., \& Waddell, G. (2011). Top management team turnover, CEO succession type, and strategic change. Journal of Business Research, 64(8), 904-910.

https://doi.org/10.1016/j.jbusres.2010.09.004

Barua, A., Lin, S., \& Sbaraglia, A. (2010) Earnings management using discontinued operations. The Accounting Review, 85(5), 1485-1509. https://doi.org/10.2308/accr.2010.85.5.1485

Bazerman, M., Giuliano, T., \& Appelman, A. (1984). Escalation of commitment in individual and group decision making. Organizational Behavior and Human Performance, 33(2), 141-152. https://doi.org/10.1016/0030-5073(84)90017-5

Berg, J., Dickhaut, J., \& Kanodia, C. (2009). The role of information asymmetry in escalation phenomena. Journal of Economic Behavior and Organization, 69(2), 135-147. https://doi.org/10.1016/j.jebo.2007.07.007

Brockner, J. (1992). The escalation of commitment to a failing course of action: toward theoretical progress. Academy of Management Review, 17(1), 39-61. https://doi.org/10.5465/amr.1992.4279568

Brody, R., \& Frank, K. (2002). Influence of prior involvement on employees' ratings. Psychological Reports, 90(1), 139-149. https://doi.org/10.2466/pr0.2002.90.1.139

Chamberlain, G. (1980). Analysis of covariance with qualitative data. Review of Economic Studies, 47(1), 225-238. https://doi.org/10.2307/2297110

Chen, G., \& Hambrick, D. (2012). CEO replacement in turnaround situations: Executive (mis) fit and its performance implications. Organization Science, 23(1), 225-243. https://doi.org/10.1287/orsc.1100.0629

Chulkov, D., \& Barron, J. (2019). Turnover in top management and de-escalation of commitment. Applied Economics, 51(23), 2534-2551. https://doi.org/10.1080/00036846.2018.1546955 
Finkelstein, S., Hambrick, D., \& Cannella, A. (2009). Strategic leadership: Theory and research on executives, top management teams, and boards. Oxford University Press. https://doi.org/10.1093/acprof:oso/9780195162073.003.0005

Gao, H., Harford, J., \& Li, K. (2017). CEO turnover-performance sensitivity in private firms. Journal of Financial and Quantitative Analysis, 52(2), 583-611. https://doi.org/10.1017/S0022109017000126

Hermalin, B., \& Weisbach, M. (2012). Information disclosure and corporate governance. The Journal of Finance, 67(1), 195-233. https://doi.org/10.1111/j.1540-6261.2011.01710.x

Huang, T., Souitaris, V., \& Barsade, S. (2019). Which matters more? Group fear versus hope in entrepreneurial escalation of commitment. Strategic Management Journal, 40(11), 1852-1881. https://doi.org/10.1002/smj.3051

Jenter, D., \& Kanaan, F. (2015). CEO turnover and relative performance evaluation. The Journal of Finance, 70(5), 2155-2184. https://doi.org/10.1111/jofi.12282

Jiang, H., Cannella, A., Xia, J., \& Semadeni, M. (2017). Choose to fight or choose to flee? A network embeddedness perspective of executive ship jumping in declining firms. Strategic Management Journal, 38(10), 2061-2079. https://doi.org/10.1002/smj.2637

Kalmanovich-Cohen, H., Pearsall, M., \& Christian, J. (2018). The effects of leadership change on team escalation of commitment. The Leadership Quarterly, 29(5), 597-608. https://doi.org/10.1016/j.leaqua.2018.03.004

Kanodia, C., Bushman, R., \& Dickhaut, J. (1989). Escalation errors and the sunk cost effect. Journal of Accounting Research, 27(1), 59-77. https://doi.org/10.2307/2491207

Kaplan, S., Kenchington, D., \& Wenzel, B. (2020). The valuation of discontinued operations and its effect on classification shifting. The Accounting Review, 95(4), 291-311. https://doi.org/10.2308/tar-2016-0235

Keil, M., \& Robey, D. (1999). Turning around troubled software projects: An exploratory study of the de-escalation of commitment to failing courses of action. Journal of Management Information Systems, 15(4), 63-87. https://doi.org/10.1080/07421222.1999.11518222

Lee, J., Keil, M., \& Wong, K. (2021). When a growth mindset can backfire and cause escalation of commitment to troubled information technology project. Information Systems Journal, 31(1), 7-32. https://doi.org/10.1111/isj.12287

Lippman, S., \& McCall, J. (1981). The economics of belated information. International Economic Review, 22(1), 135-146. https://doi.org/10.2307/2526141

Montecinos-Pearce, A., Rodrigo, P., \& Duran, I. (2020). When is escalation of commitment unstoppable in group settings? An iterative economic modeling approach to unveil the dark side of group decision-making. Managerial and Decision Economics, 41(8), 1387-1402. https://doi.org/10.1002/mde.3190

Murphy, K., \& Zimmerman, J. (1993). Financial performance surrounding CEO turnover. Journal of Accounting and Economics, 16(1-3), 273-315. https://doi.org/10.1016/0165-4101(93)90014-7

Ohlert, C., \& Weißenberger, B. (2020). Debiasing escalation of commitment: The effectiveness of decision aids to enhance de-escalation. Journal of Management Control, 30(4), 405-438. https://doi.org/10.1007/s00187-019-00290-z

Parrino, R. (1997). CEO turnover and outside succession a cross-sectional analysis. Journal of Financial Economics, 46(2), 165-197. https://doi.org/10.1016/S0304-405X(97)00028-7

Ross, J., \& Staw, B. (1993). Organizational escalation and exit: Lessons from the Shoreham Nuclear Power Plant. Academy of Management Journal, 36(4), 701-732.

Schulz-Hardt, S., Thurow-Kröning, B., \& Frey, D. (2009). Preference-based escalation: A new interpretation for the responsibility effect in escalating commitment and entrapment. Organizational Behavior and Human Decision Processes, 108(2), 175-186. https://doi.org/10.1016/j.obhdp.2008.11.001 
Schultze, T., \& Schulz-Hardt, S. (2021). Does change of responsibility reduce escalating commitment? A replication and theoretical extension. Journal of Experimental Psychology: Applied. Advance online publication. https://doi.org/10.1037/xap0000366

Shen, W., \& Cannella, A. (2002). Revisiting the performance consequences of CEO succession: The impacts of successor type, post-succession senior executive turnover, and departing CEO tenure. Academy of Management Journal, 45(4), 717-733. https://doi.org/10.5465/3069306

Simonson, I., \& Staw, B. (1992). De-escalation strategies: A comparison of techniques for reducing commitment to losing courses of action. Journal of Applied Psychology, 77(4), 419-426. https://doi.org/10.1037/0021-9010.77.4.419

Sleesman, D., Conlon, D., McNamara, G., \& Miles, J. (2012). Cleaning up the big muddy: A metaanalytic review of the determinants of escalation of commitment. Academy of Management Journal, 55(3), 541-562. https://doi.org/10.5465/amj.2010.0696

Statman, M., \& Sepe, J. (1989). Project termination announcements and the market value of the firm. Financial Management, 18(4), 74-81. https://people.bath.ac.uk/mnsrf/Teaching\%202011/statman\%20sepe.pdf

Staw, B. (1976). Knee-deep in the big muddy: A study of escalating commitment to a chosen course of action. Organizational Behavior and Human Performance, 16(1), 27-44. https://doi.org/10.1016/0030-5073(76)90005-2

Staw, B. (1997). The escalation of commitment: An update and appraisal. In Z. Shapira (Ed.), Organisational decision making (pp. 191-215). Cambridge University Press. https://psycnet.apa.org/record/1997-97037-006

Staw, B., Barsade, S., \& Koput, K. (1997). Escalation at the credit window: A longitudinal study of bank executives' recognition and write-off of problem loans. Journal of Applied Psychology, 82(1), 130-142. https://doi.org/10.1037/0021-9010.82.1.130

Staw, B., \& Ross, J. (1987). Behavior in escalation situations: antecedents, prototypes, and solutions. In B. Staw \& L. Cummings (Eds.), Research in organizational behavior (Vol. 9, pp. 39-78). JAI Press. 